\title{
Factors associated to knowledge on nosocomial infection among the staff nurses in four hospitals of Dhaka, Bangladesh
}

\author{
Mohammad Sayfur Rahman ${ }^{1}$, Ahad Mahmud Khan ${ }^{2 *}$, Najnin Nahar ${ }^{3}$ and Md. Faizul \\ Ahasan $^{4}$
}

${ }^{1}$ National Institute of Cardiovascular Diseases and Hospital, Dhaka ${ }^{2}$ Projahnmo, Johns Hopkins University, Bangladesh Office, Dhaka ${ }^{3}$ Shaheed Suhrawardy Medical College Hospital, Dhaka

${ }^{4}$ Universal Medical College, Dhaka, Bangladesh

$\triangle$ Corresponding author*: ahad_mahmud [@] hotmail.com

Article Received: 01.09.17; Revised: 28.10.17; Published online: 25 November 2017.

\begin{abstract}
Background: Nurses can play an important role in controlling nosocomial infection. The objective of this study was to assess the factors associated with level of knowledge of the staff nurses on nosocomial infection.
\end{abstract}

Methods: The study was a cross sectional study carried out among 125 staff nurses working in four selected hospitals in Dhaka city. Structured questionnaire including a set of 30 questions for assessing the knowledge level used in this study.

Results: Majority of the respondents were females (74.0\%) with a mean age of $24.7 \pm 3.3$ years. A greater proportion was educated in Diploma in Nursing (88.0\%) and had less than one year of working experience (42.4\%). Out of total score of 30, 33.6\% scored $\leq 20$, which was considered as poor knowledge, 40.8\% scored 21-25 which was considered as average knowledge, and only 25.6\% scored 26-30 which was considered as good knowledge. Educational qualification $(p=0.020)$ and duration of service experience ( $p=0.043$ ) were associated with the level of knowledge. Participation of training on infection control program was not associated with the knowledge level on nosocomial infection.

Conclusion: Knowledge of majority of the staff nurses on nosocomial infection is at poor to average level in Bangladesh. More emphasis should be given in academic curriculum, effective participation in infection control training program and hands-on training during service to reach their knowledge to a better level to ensure quality of nursing care.

Key Words: Nosocomial infection, Hospital acquired infection, Staff nurse and Knowledge

Cite Article: Rahman, M. S., Khan, A. M., Nahar, N. and Ahasan, M. F. (2016). Factors associated to knowledge on nosocomial infection among the staff nurses in four hospitals of Dhaka, Bangladesh. Journal of Molecular Studies and Medicine Research, 02(02), 99-107. Crossref: https://doi.org/10.18801/jmsmr.020217.12

This article is distributed under terms of a Creative Common Attribution 4.0 International License. 


\section{Introduction}

Nosocomial infections are acquired in hospital by the patient who was admitted for a reason other than that infection that results in substantial morbidity and mortality worldwide (Ducel et al., 2002). The prevalence rate of nosocomial infection is $3.0-20.7 \%$ and the incidence rate is $5-10 \%$ (Samuel et al., 2010). According to the report of World Health Organization (WHO) about $8.7 \%$ nosocomial infections were noticed among the hospitalized patients (Ducel et al., 2002). Developing countries are about 20 times more likely to develop nosocomial infection than developed countries (Bello et al., 2011). Nosocomial infection is considered when it becomes evident 48 hours or more after hospital admission or within 30 days of release following inpatient care (Ducel et al., 2002; Samuel et al., 2010). The pathogens are often transmitted from patient to patient by way of health care staff due to lack of knowledge and practice of control measures of spreading infection (Suchitra and Devi, 2007). The common types of hospital acquired infections are urinary tract, surgical wounds, respiratory tract and blood stream related infections (Kamunge et al., 2015).

Appropriate measures prerequisite for dropping the incidence of hospital acquired infections are welldocumented in literature (Ducel et al., 2002; Suchitra and Devi, 2007; Tavolacci et al., 2008). Evidence suggests that the spread of nosocomial infections could be due to a breach in knowledge among healthcare staff (Kamunge et al., 2015; Najeeb and Taneepanichsakul, 2008; Sickder et al., 2010; Vij et al., 2001). Clinical staff such as doctors and nurses act as potential vectors for carrying of the infections (Kamunge et al., 2015). Nurses play significant roles in the members of health care team and their well-researched knowledge and good practice can contribute to infection control and reduce nosocomial infection (Hawker, 1999). Adequate attention needs to pay to imparting knowledge to staff nurses about measures to control nosocomial infections (Bryce et al., 2007).

Low level of knowledge on nosocomial infection among the staff nurses of low- and middle-income countries has been illustrated in previous studies. The mean knowledge and practice of nurses regarding the infection control measures was $73 \%$ and $63 \%$ respectively reported in a study in India (Vij et al., 2001). Another study in Maldives revealed that nurses had high knowledge score, but low practice score (Najeeb and Taneepanichsakul, 2008). Poor knowledge on infection control among the nurses was reported conducted in a government medical college in Bangladesh (Sickder et al., 2010). Nurses can avert nosocomial infections by their knowledge, attitude and practice. However, the literature on nurses' knowledge regarding nosocomial infection is very few in Bangladesh. Therefore, this study was designed to assess the level of their knowledge on nosocomial infection and associated factors among staff nurses.

\section{Materials and Methods}

Study participants: This cross-sectional study was conducted among the staff nurses working in four hospitals in Dhaka, Bangladesh.

Sample size: The sample size was 125 . It was calculated taking into consideration the fair knowledge of nurse on nosocomial infection as 53.9\% (Fashafsheh et al., 2015) with allowable error of 0.09, confidence interval of $95 \%$ and adjusting for $5 \%$ non-response.

Selection criteria: Staff nurses who were present on duty in the hospital, willingness to participate and had enough time to participate without causing any problem in care of patients were included in the study. Those were busy and did not give consent were excluded.

Research instrument: Questionnaires were developed by the researchers themselves. There were thirty questions to assess the level of knowledge on nosocomial infection (Table 01). The correct response of each item received a score of ' 1 ' and ' 0 ' for incorrect response or if answer was not known. The total score ranged from 0 to 30 . The higher score indicated the higher level of knowledge. A score of $\leq 20$ was considered poor, $21-25$ as average and $\geq 26$ as good. The questionnaire also contained questions for data on the age, sex, educational qualification, duration of service experience and participation on infection control training. 
Data collection and analysis: Data were collected by face to face interview. Analysis was done using Statistical Package for Social Sciences (SPSS) version 21.0. Descriptive statistics were used to summarize the data obtained. Chi-square test was done to find out the associated factors of level of knowledge. The $p$-value $<0.05$ was considered statistically significant.

Ethical consideration: Ethical approval was taken from ASA University Bangladesh authority to conduct the study. Formal approval was obtained from the authority of respective hospitals. Informed written consent was taken from the respondents before conducting interview. Confidentiality was strictly maintained.

Table 01. Assessment of knowledge level on nosocomial infection

\begin{tabular}{|c|c|c|}
\hline No. & Questions & Score \\
\hline 01. & What is nosocomial infection? & 1 \\
\hline 02. & $\begin{array}{l}\text { Who are the at-risk group of nosocomial infection? } \\
\text { a. Patient } \\
\text { b. Patients attendant } \\
\text { c. Doctors } \\
\text { d. Nurses } \\
\text { e. All hospital staff }\end{array}$ & 5 \\
\hline 03 & $\begin{array}{l}\text { What are the most common nosocomial infections? } \\
\text { a. Urinary tract infection } \\
\text { b. Respiratory tract infection } \\
\text { c. Surgical site infection } \\
\text { d. Septicemia }\end{array}$ & 4 \\
\hline 04 & $\begin{array}{l}\text { What are the risk factors for nosocomial infections? } \\
\text { a. Long stay in hospital } \\
\text { b. Decreased immunity } \\
\text { c. Malnutrition }\end{array}$ & 3 \\
\hline 05 & $\begin{array}{l}\text { What are the consequences of nosocomial infection? } \\
\text { a. Increases length of stay in hospital } \\
\text { b. Financial loss } \\
\text { c. Mental stress }\end{array}$ & 3 \\
\hline 06 & $\begin{array}{l}\text { What are the measures for prevention of nosocomial infections? } \\
\text { a. Proper hand washing } \\
\text { b. Proper sterilization of instruments } \\
\text { c. Proper care of urinary catheter } \\
\text { d. Isolation of highly contagious patients }\end{array}$ & 4 \\
\hline 07 & Nosocomial infection is also known as hospital acquired infection. & 1 \\
\hline 08 & $\begin{array}{l}\text { Infections incubating, but not clinically apparent, at admission are excluded from } \\
\text { nosocomial infection. }\end{array}$ & 1 \\
\hline 09 & $\begin{array}{l}\text { Signs and symptoms of these infections can be seen after } 48-72 \text { hours of } \\
\text { hospitalization. }\end{array}$ & 1 \\
\hline 10 & It can be manifested after discharge form hospital. & 1 \\
\hline 11 & The patient can be infected by a microorganism that he or she is already carrying & 1 \\
\hline 12 & Urinary tract infection is the most common nosocomial infection. & 1 \\
\hline 13 & $\begin{array}{l}\text { At least } 80 \text { percent of nosocomial urinary infections are attributable to the use of an } \\
\text { indwelling urethral catheter. }\end{array}$ & 1 \\
\hline 14 & $\begin{array}{l}\text { Urinary catheter should be used for limited duration to reduce risk of nosocomial } \\
\text { infection. }\end{array}$ & 1 \\
\hline 15 & A nurse is required to dispose a suction catheter immediately after single use. & 1 \\
\hline 16 & $\begin{array}{l}\text { Gloves should be changed after touching potential sources of microbial colonization, } \\
\text { such as diapers, ventilator tubing, or Foley catheters. }\end{array}$ & 1 \\
\hline
\end{tabular}




\section{Results}

\section{Socio-demographic characteristics}

Table 02 shows the socio-demographic characteristics of the respondents. The mean age of the respondents was $24.74 \pm 3.33$ years and age of the majority was in $\leq 25$ years group $(65.6 \%)$. Malefemale ratio was 1:2.9. Most of respondents were educated in diploma in nursing (88.0\%) and duration of service experience was less than 1 year (42.4\%).

\section{Knowledge on nosocomial infection}

Table 03 and Table 04 present frequencies for correct answers to the theoretical and practical knowledge questions related to nosocomial infection. The correct answers to the knowledge questions on high risk groups of nosocomial infection - patients (90.4\%), patients' attendance $(64.0 \%)$, doctors $(59.2 \%)$, nurses $(68.8 \%)$ and hospital staff $(73.6 \%)$. They correctly identified urinary tract infection $(90.4 \%)$, respiratory tract infection $(73.6 \%)$, surgical site infection $(59.2 \%)$ and septicemia $(36.0 \%)$ as the nosocomial infection. They correctly mentioned long stay in hospital $(89.6 \%)$, decreased immunity $(73.6 \%)$ and malnutrition $(37.6 \%)$ as the risk factors. They correctly answered questions on preventive measures - proper hand washing (87.2\%), proper sterilization of instruments (90.4\%), proper care of urinary catheter $(75.2 \%)$ and isolation of highly contagious patients $(76.8 \%)$.

\section{Factors associated with level of knowledge on nosocomial infection}

Table 05 shows that out of total score of 30, 42 (33.6\%) of the nurses scored 20 or less, which was considered as poor score, 51 (40.8\%) scored 21-25 which was average score, and only31 (25.6\%) scored 26-30 which was good score. Although level of knowledge increased with ages, it was not statistically significant. Level of knowledge was found better in female than in male, which was not significant. Level of knowledge was lower who completed diploma in nursing than those who completed B.Sc. in nursing; the level of knowledge was even higher who completed master of public health. The association between educational qualification and level of knowledge was statistically significant $(\mathrm{p}=0.020)$. The proportion of nurses with good knowledge increased with the duration of service experience which was also statistically significant $(\mathrm{p}=0.043)$. About $24 \%$ nurses reported that they participated in infection control training program; however, it was not associated with the level of knowledge in nosocomial infection.

\section{Discussion}

Nosocomial infection is a very important factor in health status all around the world. As an important member of health care team, nurses have very important role in preventing nosocomial infection. Therefore, up to date knowledge and nursing skills can play important roles in infection control. This study highlighted level of knowledge on nosocomial infection and associated factors among staff nurses in four hospitals in Dhaka city.

Our study reported that about 33\% nurses had poor knowledge and about $40 \%$ had average knowledge on nosocomial infection. This finding is consistent with few other studies in low- and middle-income countries. A study in Palestine hospital reported about half of the respondents had fair knowledge and one quarter had poor knowledge on infection control (Fashafsheh et al., 2015). Average to lower level of knowledge was also reported in Northern Nigeria (Abdulraheem et al., 2012) in Asaba (Isara and Ofili, 2010), in Jamaica (Vaz et al., 2010) and in Philippines (Labrague et al., 2012). A study in India reported the level of knowledge of $10 \%$ nurses was excellent, $20 \%$ was good, $30 \%$ had fair and $40 \%$ had poor (Suchitra and Devi, 2007). However, the scoring system of those studies were different from our study.

Most of the nurses were below 25 years of age and were female. Nursing in Bangladesh is a female dominant profession or less number of males involved in this profession. Diploma in nursing was the highest education level of most of the respondents. Majority of the nurses had experience of less than one year. This study found significant association with educational qualification and service experience. Previous studies showed that nurses' knowledge is influenced by basic and continuing education, service experience and in-service training (Evans and Donnelly, 2006; Pancorbo-Hidalgo et 
al., 2007). A similar type of study reported no relationship between knowledge or practice regarding infection control and age, years of experience, and training course of the studied group (Fashafsheh et al., 2015). Another study indicated that, factors such as age and years of experience did not contribute to acquisition of knowledge or practice of infection control (Hamid et al., 2010). Graduate nurses possess more knowledge and higher levels of practice than diploma nurses revealed in previous studies (Taneja et al., 2009; Vij et al., 2001). According to Sickder et al. (2010) the knowledge on infection were relatively lower among the majority of the nurses which might be due to background of the respondents including education, training and working experience (Sickder et al., 2010).

Regarding individual items, the study showed that majority of the nurses had average knowledge about risk group, common nosocomial infection and measures of prevention. A similar study found that most of the respondents had satisfactory level of knowledge regarding causes, source, mode of transmission of nosocomial infections and infection control measures in general (Zeinab et al., 2015). Another study reported that majority of their participants were aware with, what infection is, and how it is transmitted (Ibrahim et al., 2011). In another study, approximately two thirds of participants hadn't had previous courses on infection control (Fashafsheh et al., 2015) and only 8\% had previously undergone infection control training such as in-service education, short-term courses, or a training program (Taneja et al., 2009). Lack of training courses might be a factor for lower level of knowledge. However, our study did not find any relationship between training courses and level of knowledge. This might be due to lack of refreshers training or ineffective training.

\section{Conclusion}

Knowledge of majority of the staff nurses on nosocomial infection is at average level in Bangladesh. The academic curriculum should be more focused on both theoretical and practical knowledge of infection control. Effective training sessions should be organized at the time of hire and in-service periodically. This study could contribute to nursing education, nursing practice and development of further research in the nursing profession.

\section{Acknowledgements}

Authors would like to acknowledge all the staff nurses who participated and also the authorities for giving permission to conduct the study in their hospitals.

\section{Conflicts of Interest}

None of the authors have any conflicts of interest with this study.

\section{Author Contribution}

Work of this article was carried out in cooperation and understanding between all authors mentioned in manuscript. Mohammad Sayfur Rahman and Ahad Mahmud Khan developed concept and designed the study, wrote the methodology, investigate works/researches, performed statistical analysis and interpretation; and wrote the first draft of the manuscript. Md. Faizul Ahasan managed the analyses, revision of the study. Najnin Nahar managed the literature searches and manuscript update. All authors read and approved the final manuscript.

\section{References}

[1]. Abdulraheem, I., Amodu, M., Saka, M., Bolarinwa, O. and Uthman, M. (2012). Knowledge, awareness and compliance with standard precautions among health workers in north eastearn Nigeria. J Community Med Health Edu, 2(3), 1-5.

[2]. Bello, A. I., Asiedu, E. N., Adegoke, B. O., Quartey, J. N., Appiah-Kubi, K. O. and Owusu-Ansah, B. (2011). Nosocomial infections: knowledge and source of information among clinical health care students in Ghana. International Journal of General Medicine, 4, 571. 
https://doi.org/10.2147/IJGM.S16720

PMid:21887110 PMCid:PMC3160866

[3]. Bryce, E. A., Scharf, S., Walker, M. and Walsh, A. (2007). The infection control audit: the standardized audit as a tool for change. American journal of infection control, 35(4), 271-283.

https://doi.org/10.1016/j.ajic.2006.05.293

PMid:1748300

[4]. Ducel, G., Fabry, J. and Nicolle, L. (2002). Prevention of hospital acquired infections: a practical guide. Prevention of hospital acquired infections: a practical guide (Ed. 2).

[5]. Evans, R. J. and Donnelly, G. W. (2006). A model to describe the relationship between knowledge, skill, and judgment in nursing practice. Paper presented at the Nursing Forum.

https://doi.org/10.1111/j.1744-6198.2006.00053.x

PMid:17076797

[6]. Fashafsheh, I., Ayed, A., Eqtait, F. and Harazneh, L. (2015). Knowledge and Practice of Nursing Staff towards Infection Control Measures in the Palestinian Hospitals. Journal of Education and Practice, 6(4), 79-90.

[7]. Hamid, M., Aziz, N. A., Anita, A. and Norlijah, O. (2010). Knowledge of blood-borne infectious diseases and the practice of universal precautions amongst health-care workers in a tertiary hospital in Malaysia. Southeast Asian Journal of Tropical Medicine and Public Health, 41(5), 1192.

[8]. Hawker, J. (1999). A survey of the implementation of health service guidelines on arrangements for infection control in health trusts in the West Midlands. Communicable disease and public health/PHLS, 2(1), 54-58.

[9]. Ibrahim, Y. S., Said, A. R. M. and Hamdy, G. K. (2011). Assessment of infection control practices in a neonatal intensive care unit (NICU). Egyptian J Comm Med, 29, 27-45.

[10]. Isara, A. and Ofili, A. (2010). Knowledge and practice of standard precautions among health care workers in the Federal Medical Centre, Asaba, Delta State, Nigeria. The Nigerian postgraduate medical journal, 17(3), 204-209.

[11]. Kamunge, E., Cahill, T., Zipp, G., \& Parasher, R. (2015). Knowledge, attitudes and practices of registered nurses regarding the spread of nosocomial infections and the impact of organizational support. Antimicrobial Resistance and Infection Control, 4(S1), p. 60.

https://doi.org/10.1186/2047-2994-4-S1-P60

PMCid:PMC4474882

[12]. Labrague, L. J., Rosales, R. A. and Tizon, M. M. (2012). Knowledge and Compliance of Standard Precautions among Student Nurses. International journal of advanced nursing studies, 1(2), 84-97. https://doi.org/10.14419/ijans.v1i2.132

[13]. Najeeb, N. and Taneepanichsakul, S. (2008). Knowledge, attitude, and practice of standard and transmission-based precautions of doctors and nurses in tertiary and secondary health care settings of Maldives. Journal of Health Research, 22, 45-48.

[14]. Pancorbo-Hidalgo, P. L., García-Fernández, F. P., López-Medina, I. M. and López-Ortega, J. (2007). Pressure ulcer care in Spain: nurses' knowledge and clinical practice. Journal of Advanced Nursing, 58(4), 327-338.

https://doi.org/10.1111/j.1365-2648.2007.04236.x

PMid:17442040

[15]. Samuel, S., Kayode, O., Musa, O., Nwigwe, G., Aboderin, A., Salami, T. and Taiwo, S. (2010). Nosocomial infections and the challenges of control in developing countries. African journal of clinical and experimental microbiology, 11(2).

https://doi.org/10.4314/ajcem.v11i2.53916

PMCid:PMC2822847

[16]. Sickder, H. K., Sae-Sia, A. P. D. W. and Petpichetchian, A. P. D. W. (2010). Nurses' Knowledge and Practice Regarding Prevention of Surgical Site Infection in Bangladesh.

[17]. Suchitra, J. and Devi, N. L. (2007). Impact of education on knowledge, attitudes and practices among various categories of health care workers on nosocomial infections. Indian Journal of Medical Microbiology, 25(3), 181.

https://doi.org/10.4103/0255-0857.34757

PMid:1790163

[18]. Taneja, J., Bibha Bati, M., Aradhana, B., Poonam, L., Vinita, D. and Archana, T. (2009). Evaluation of knowledge and practice amongst nursing staff toward infection control measures in a 
tertiary care hospital in India. The Canadian Journal of infection control: the official journal of the Community \& Hospital Infection Control Association-Canada=Revue canadienne de prevention des infections, 24(2), 104-107.

[19]. Tavolacci, M. P., Ladner, J., Bailly, L., Merle, V., Pitrou, I. and Czernichow, P. (2008). Prevention of nosocomial infection and standard precautions: knowledge and source of information among healthcare students. Infection Control \& Hospital Epidemiology, 29(07), 642-647.

https://doi.org/10.1086/588683

PMid:18611166

[20]. Vaz, K., McGrowder, D., Alexander-Lindo, R., Gordon, L., Brown, P. and Irving, R. (2010). Knowledge, awareness and compliance with universal precautions among health care workers at the University Hospital of the West Indies, Jamaica. The international journal of occupational and environmental medicine, 1 (4 October).

[21]. Vij, A., Williamson, S. and Gupta, S. (2001). Knowledge and practice of nursing staff towards infection control measures in a tertiary care hospital. Journal of the Academy of Hospital Administration, 13(2), 1-6.

[22]. Zeinab, M., El-Sayed, A. G. and Mohga Abdel-Aziz. (2015). Nurses' Knowledge and Practice for Prevention of Infection in Burn Unit at a University Hospital: Suggested Nursing Guidelines. IOSR Journal of Nursing and Health Science, 4(4), 62-69.

Table 02. Socio-demographic characteristics of the respondents

\begin{tabular}{|c|c|c|}
\hline Characteristics & Number & Percentage \\
\hline \multicolumn{3}{|l|}{ Age } \\
\hline Up to 25 years & 82 & 65.6 \\
\hline 26 - 30 years & 34 & 27.2 \\
\hline $31-35$ years & 9 & 7.2 \\
\hline \multicolumn{3}{|l|}{ Sex } \\
\hline Male & 32 & 25.6 \\
\hline Female & 93 & 74.4 \\
\hline \multicolumn{3}{|l|}{ Marital status } \\
\hline Single & 82 & 65.6 \\
\hline Married & 43 & 34.4 \\
\hline \multicolumn{3}{|c|}{ Highest educational qualification } \\
\hline Diploma in Nursing & 110 & 88.0 \\
\hline B.Sc. in Nursing & 13 & 10.4 \\
\hline Master of Public Health & 2 & 1.6 \\
\hline \multicolumn{3}{|c|}{ Duration of service experience } \\
\hline$<1$ year & 53 & 42.4 \\
\hline $1-3$ years & 34 & 27.2 \\
\hline $4-6$ years & 21 & 16.8 \\
\hline$>6$ years & 17 & 13.6 \\
\hline
\end{tabular}

Table 03. Frequencies for correct answers to knowledge questions

\begin{tabular}{l|l|l}
\hline Survey questions & $\begin{array}{l}\text { No. of correct } \\
\text { answers }\end{array}$ & Percentage \\
\hline Concept on nosocomial infection & 75 & 60.0 \\
\hline Risk group of nosocomial infection & 113 & 90.4 \\
\hline Patients & 80 & 64.0 \\
Patients' attendant & 74 & 59.2 \\
Doctors & 86 & 68.8 \\
Nurses & 92 & 73.6 \\
All hospital staff & \multicolumn{2}{l}{} \\
\hline Identifying most common nosocomial infections & 113 & 90.4 \\
\hline Urinary tract infection & 92 & 73.6
\end{tabular}




\begin{tabular}{|c|c|c|}
\hline $\begin{array}{l}\text { Surgical site infection } \\
\text { Septicemia }\end{array}$ & $\begin{array}{l}74 \\
45 \\
\end{array}$ & $\begin{array}{l}59.2 \\
36.0\end{array}$ \\
\hline \multicolumn{3}{|l|}{ Risk factors for nosocomial infection } \\
\hline Long stay in hospital & 112 & 89.6 \\
\hline Decreased immunity & 92 & 73.6 \\
\hline Malnutrition & 47 & 37.6 \\
\hline \multicolumn{3}{|l|}{ Consequences of nosocomial infection } \\
\hline Increases length of stay in hospital & 100 & 80.0 \\
\hline Financial loss & 84 & 67.2 \\
\hline Mental stress & 71 & 56.8 \\
\hline \multicolumn{3}{|l|}{ Measures of prevention } \\
\hline Proper hand washing & 109 & 87.2 \\
\hline Proper sterilization of instruments & 113 & 90.4 \\
\hline Proper care of urinary catheter & 94 & 75.2 \\
\hline Isolation of highly contagious patients & 96 & 76.8 \\
\hline
\end{tabular}

Table 04. Frequencies for correct answers to knowledge questions (cont.)

\begin{tabular}{|c|c|c|}
\hline Survey questions & $\begin{array}{l}\text { No. of correct } \\
\text { answers }\end{array}$ & Percentage \\
\hline Nosocomial infection is also known as hospital acquired infection & 101 & 80.8 \\
\hline $\begin{array}{l}\text { Infection incubating, but not clinically apparent at admission are } \\
\text { excluded from nosocomial infection }\end{array}$ & 60 & 48.0 \\
\hline $\begin{array}{l}\text { Signs and symptoms of these infections can be seen after } 48-72 \\
\text { hours of hospitalization }\end{array}$ & 78 & 62.4 \\
\hline It can be manifested after discharge from hospital & 107 & 85.6 \\
\hline $\begin{array}{l}\text { The patient can be infected by a microorganism that he or she is } \\
\text { already carrying }\end{array}$ & 103 & 82.4 \\
\hline Urinary tract infection is the most common nosocomial infection & 107 & 85.6 \\
\hline $\begin{array}{l}\text { At least } 80 \% \text { of nosocomial urinary infections are attributable to } \\
\text { the use of an indwelling urethral catheter }\end{array}$ & 97 & 77.6 \\
\hline $\begin{array}{l}\text { Urinary catheter should be used for limited duration to reduce risk } \\
\text { of nosocomial infection. }\end{array}$ & 95 & 76.0 \\
\hline $\begin{array}{l}\text { A nurse is required to dispose a suction catheter immediately after } \\
\text { single use. }\end{array}$ & 110 & 88.0 \\
\hline $\begin{array}{l}\text { Gloves should be changed after touching potential sources of } \\
\text { microbial colonization, such as diapers, ventilator tubing, or Foley } \\
\text { catheters. }\end{array}$ & 123 & 98.4 \\
\hline
\end{tabular}


Table 05. Factors associated with level of knowledge on nosocomial infection

\begin{tabular}{|c|c|c|c|c|}
\hline \multirow[t]{3}{*}{ Characteristics } & \multicolumn{3}{|c|}{ Level of knowledge on nosocomial infection } & \multirow[t]{3}{*}{$p$-value* } \\
\hline & Poor & Average & Good & \\
\hline & N (\%) & $\mathrm{N}(\%)$ & $\mathrm{N}(\%)$ & \\
\hline \multicolumn{5}{|l|}{ Age (years) } \\
\hline$\leq 25$ years & $30(36.6)$ & $34(41.5)$ & $18(22.0)$ & 0.208 \\
\hline 26-30 years & $12(35.3)$ & $12(35.3)$ & $10(29.4)$ & \\
\hline 31-35 years & $0(0.0)$ & $5(55.6)$ & $4(44.4)$ & \\
\hline \multicolumn{5}{|l|}{ Sex } \\
\hline Male & $16(50.0)$ & $10(31.3)$ & $6(18.8)$ & 0.075 \\
\hline Female & $26(28.0)$ & $41(44.1)$ & $26(28.0)$ & \\
\hline \multicolumn{5}{|c|}{ Highest educational qualification } \\
\hline Diploma in Nursing & $41(37.3)$ & $45(40.9)$ & $24(21.8)$ & 0.020 \\
\hline B.Sc. in Nursing & $1(7.7)$ & $6(42.2)$ & $6(46.2)$ & \\
\hline Masterof Public Health & $0(0.0)$ & $0(0.0)$ & $2(100.0)$ & \\
\hline \multicolumn{5}{|c|}{ Duration of service experiences } \\
\hline$\leq 1$ year & $19(35.8)$ & $25(47.2)$ & $9(17.0)$ & 0.043 \\
\hline $1-3$ years & $15(44.1)$ & $11(32.4)$ & $8(23.5)$ & \\
\hline$>3$ years & $8(21.1)$ & $15(39.5)$ & $15(39.5)$ & \\
\hline \multicolumn{5}{|c|}{ Participation in infection control training } \\
\hline Yes & $8(26.7)$ & $16(53.3)$ & $6(20.0)$ & 0.277 \\
\hline No & $34(35.8)$ & $35(36.8)$ & $26(27.4)$ & \\
\hline Total & $42(33.6)$ & $51(40.8)$ & $31(25.6)$ & \\
\hline
\end{tabular}

${ }^{*}$ Chi-square test 